\section{Clinton's trade troubles}

\section{President Bill Clinton needs to make up his mind on trade even if he offends some of his supporters in the process.}

THE trouble with populism is that it feeds on itself. That is what President Bill Clinton will now be sensing in his efforts to map out a strategy on international trade. During his election campaign last year, he gave US voters the firm impression that the preservation of jobs in the United States was at the front of his mind; he also talked about the need to make US industry more competitive. "Fair trade", not free trade, was the motto.

None of that was inconsistent with Clinton's fine speech on trade two weeks ago, when he urged the United States to continue to make its way in the world by being more competitive than others, not protectionist; "we must compete, not retreat" was the slogan. The difficulty is that many of those who have listened to these speeches have preferred to seize upon the forms of words Clinton used during the election to urge on his new administration new forms of protection. "Are there not American jobs to be saved?", these populists from US industry are asking, knowing that they can rally a host of allies in the Congress to that cause.

The clamour is in danger of getting out of hand, partly encouraged by conflicting signals from the president himself. Only a few days before his speech on trade, he told Boeing workers that he would take up again the long dispute between the United States and the European members of the Airbus consortium, apparently resolved for a five-year period only last year. Meanwhile, anti-dumping tariffs on European steel are in abeyance only, while some unfortunate Japanese manufacturers of light transport vehicles are penalized with entry tariffs ten times what they used to be. US semiconductor manufacturers have been persuaded not to press for a public declaration that Japan has violated the iniquitous bilateral agreement in the field by failing last year to buy 20 per cent of its microchips from US manufacturers (the figure was only 17 per cent), while the International Trade Commission in Washington is up to its eyes in solemn investigations of the trade in lentils, mackerel and in Canadian meat, against which US producers also seek protection.

These are both tedious and arbitrary ways of arranging that trade is fair. Lobbying by domestic industries suffering from overseas competition is inevitably the trigger for investigation. Everybody agrees with one of the principles of the General Agreement on Tariffs and Trade (GATT) that goods should not be exported from one place to another at prices that are unfairly low, either by government subsidy or by manufacturers seeking a larger share of a market, but that leaves ample uncertainty about what prices would be fair. The determinations made by the International Trade Commission in Washington (its counterparts in Brussels often seem as self-interested) too often fail to carry conviction in the outside world.
The United States is also among the most ardent of industrialized nations in the pursuit of what GATT calls "non-tariff restraints on trade". Industrial nations, to their collective shame, all defend themselves against imports of textiles through the infamous Multi-Fibre Agreement, whose victims are both their own taxpayers and the developing countries. But the bilateral agreement with Japan on semiconductors, with its rules for regulating the prices to be charged in third countries as well as its quota arrangements for sustaining US exports to Japan, the various versions of the "Buy America" acts that tilt the balance of purchasing by US public authorities against supplies from overseas and the restraint on international trade in corporate shares of certain kinds (airlines, for example) are all ways of keeping out of the United States goods and even capital from elsewhere.

But does not everybody practise such stratagems? Certainly the habit is deeply ingrained. The French device, some years ago, of requiring that imported video-recorders should be tested for safety at a complex of railway sidings at Poitiers probably dented the sales of Japanese manufacturers for a while. But such tricks, not easily proved to be illegal, as well as the restrictive legislation that abounds, conflict with the underlying principle that free trade ultimately benefits all parties to the transaction. So much is proved by the way in which international trade has been the fastest growing component of the world economy for the past three decades.

So what should President Clinton do? A mood-maker if ever there was one, his first responsibility should be to seek to change the way his constituents think. Sure, there are problems about jobs, and perhaps a need for transitional assistance in some industries (not ruled out by GATT), but imported goods, if they are cheaper than the domestic kind, are also a boon and will, in the long run, free people to make products of greater value. The new president, with his emphasis on the improvement of public education, has obviously recognized the importance of preparing for that long run. He should more clearly explain his motives to those who elected him. There is a sense in which providing jobs in smokestack industries now is a recipe for making sure that there are only smokestack industries in decades to come.

Clinton should also say what he will do to rescue the almost negotiated new GATT agreement from desuetude by default. Heads of government have been meeting around the world for the past two years to proclaim the importance of this treaty, and to promise that they will exert every sinew to bring it into effect. The ambiguities that can be read into Clinton's pronouncements on trade are a licence for people elsewhere to find new causes for grumbling at what is proposed. Clinton, if he wished, could break the logjam simply by declaring that he intends to do just that. And the United States, with its enviable flexible economy, would be the chief beneficiary. Job-creation would leap ahead. So it would elsewhere, which is why the grumbles, domestic and otherwise, should be overridden. 